\title{
Papillary tumours of the minor salivary glands
}

\author{
J. S. WHITTAKER AND E. P. TURNER
}

The departments of Pathology, Withington Hospital, Manchester, and the Dental Hospital of Manchester.

SYNOPSIS The clinical and histological features of oncocytic adenomatous hyperplasia, papillary adenoma, and papillary adenocarcinoma of the oral cavity are described, and the literature is reviewed. Histological features which may be of value in distinguishing between benign and malignant variants are described, and in view of the slow growth rate of most of these tumours, the importance of long-term follow-up is stressed.

Papillary tumours of the minor salivary glands are quite rare. Most of these lesions are described in the literature under the heading 'papillary cystadenoma' which histologically resembles an adenolymphoma without the lymphoid component.

The earliest published reference to the minor salivary gland lesion was made by Skorpil (1941) in a paper entitled (translated) 'Papillary cystadenoma of the major and minor salivary glands'. His series included two intraoral minor salivary gland tumours. Although several descriptions of the minor salivary gland lesions have been published, particularly in the United States, no similar reports have appeared in Great Britain. Lucas (1973) makes brief reference to the lesion, and Evans and Cruickshank (1970) observe that 'tumour-like growths that resemble adenolymphomas occur, but are devoid of the lymphocytic component and a capsule', and these may present in the minor salivary glands of the oral cavity, larynx, nasal cavity, lachrymal caruncle, and tear sac.

Table I lists articles describing the oral lesions that have been published up to the present time; in 1960 Chaudhry et al reviewed eight cases reported before that time. From this table it will be seen that, of the 27 cases reported, the majority of the tumours presented in males (17 M: $6 \mathrm{~F}: 4$ sex not stated). The average age of presentation in 17 cases was 53 years, the ages ranging from 28 to 78 years, the majority (all but two cases) being over the age of 40 years. These details correspond with the characteristics of the parotid adenolymphoma (Evans and Cruickshank, 1970). The palate was the commonest site of presentation (11 cases). The history of the lesions before treatment is often vague and unreliable because they produce minimal symptoms and grow slowly.

Received for publication 25 February 1976
In two cases histories of 'at least' five years (Parnes, 1966) and six years (Brooks et al, 1956) have been reported. The tumour is generally regarded as benign although some authors express doubt on this point (Castigliano and Gold, 1954; Brooks et al, 1956; Brown et al, 1959; Vellios and Shafer, 1959). Clinically the lesion may present a papillated surface (Abrams and Finck, 1969).

The histological features described in the published cases, while having in common a papillary and/or cystic growth pattern, show some variation, particularly in the type of epithelium present. Not all reports mention an eosinophilic or oncocytic type of epithelium, while other features, such as goblet cells or stromal myxomatous change, are mentioned in some instances. Relatively few of the tumours are described as being macroscopically cystic.

During the course of a review of minor salivary gland tumours (to be published separately) we have encountered five cases in which a papillary pattern was a predominant feature and which did not show any diagnostic features enabling them to be placed in one of the main histological groups of salivary gland tumours as described by Foote and Frazell (1954) or Evans and Cruickshank (1970). A further case (case 2) was referred to us for an opinion and is included in the cases described here.

The clinical features of the six cases are summarized in table II. Four of the patients were male, and two female, with an average age of 63 years. Four tumours arose in the palate, especially near the junction of hard and soft palates, one in the upper lip, and one in the buccal mucosa.

\section{Case reports}

CASE 1

A man aged 65 attended for routine dental treatment, and 'an area of hyperplasia', $6 \mathrm{~mm}$ in diameter 795 


\begin{tabular}{|c|c|c|c|c|c|c|}
\hline Author & Sex & Age & Site & Length of history & Treatment & Follow-up \\
\hline Skorpil (1941) & $\begin{array}{l}\mathbf{M} \\
\mathbf{M}\end{array}$ & $\begin{array}{l}78 \\
28\end{array}$ & Tonsil & $18 \mathrm{yr}$ & Excision & 2 recurrences \\
\hline Hobaek (1949) & $\mathbf{F}$ & 45 & Palate & 12 yr & $\begin{array}{l}\text { Excision } \\
\text { Radiotherapy }\end{array}$ & - \\
\hline Castigliano and Gold (1954) & $\mathbf{M}$ & 58 & Palate & Vague-at least $6 \mathrm{wk}$ & Excision & - \\
\hline Vellios and Davidson (1955) & - & 一 & Palate & No clinical data given & & \\
\hline \multirow{2}{*}{ Brooks et al (1956) } & $\mathbf{M}$ & 31 & Palate & 一 & Excision & 1 recurrence \\
\hline & $\mathbf{M}$ & 63 & Palate & At least 6 yr & Excision & - \\
\hline \multirow[t]{2}{*}{ Bernier and Bhaskar (1958) } & $\mathbf{M}$ & - & Buccal mucosa & No clinical data given & & \\
\hline & $\mathbf{F}$ & 53 & Buccal mucosa & No clinical data given & & \\
\hline Brown et al (1959) & - & 一 & Cheek & No clinical data given & & \\
\hline \multirow[t]{2}{*}{ Vellios and Shafer (1959) } & $\mathbf{M}$ & - & Cheek & No clinical data given & & \\
\hline & $\begin{array}{l}\mathbf{M} \\
\mathbf{F}\end{array}$ & - & Palate & No clinical data given & & \\
\hline Chaudhry et al (1960) & $\mathbf{M}$ & 64 & Buccal sulcus & No clinical data given & Excision & - \\
\hline Fine et al (1960) & No $\mathrm{r}$ & cases & ight listed from lit & ture & & \\
\hline Edwards (1960) & $\mathbf{M}$ & 63 & Palate & - & Excision & No recurrence \\
\hline \multirow[t]{2}{*}{ Veronesi and Corbetta (1960) } & $\mathbf{M}$ & 42 & Lower lip & $1 \mathrm{yr}$ & Excision & - \\
\hline & $\mathbf{M}$ & 73 & Lower lip & $7 \mathrm{mth}$ & Excision & - \\
\hline \multirow[t]{2}{*}{ Chaudhry et al (1961) } & $\mathrm{F}$ & 40 & Floor of mouth & No clinical data given & & \\
\hline & $\mathbf{F}$ & 40 & Mandible & No clinical data given & & \\
\hline Calhoun et al (1965) & $\mathbf{F}$ & 51 & Upper lip & $10 \mathrm{~d}$ & - & 一 \\
\hline Parnes (1966) & $\mathbf{M}$ & 53 & Cheek & At least $5 \mathrm{yr}$ & 一 & - \\
\hline Stuteville and Corley (1967) & $\mathbf{M}$ & 58 & Cheek & $7 \mathrm{mth}$ & 一 & - \\
\hline Epker and Henny (1969) & Disc & d, but & new cases report & & & \\
\hline Abrams and Finck (1969) & $\mathbf{M}$ & 71 & Palate & At least $3 \mathrm{mth}$ & - & - \\
\hline Crocker et al (1970) & 2 cas & -no de & ils given & & & \\
\hline Crocker et al (1972) & $\mathbf{M}$ & 71 & Buccal mucosa & - & Excision & 一 \\
\hline Jensen and Reingold (1973) & $\mathbf{M}$ & 48 & Hard palate & - & Excision & - \\
\hline
\end{tabular}

Table I Previously published cases of papillary adenoma or cystadenoma

\begin{tabular}{|c|c|c|c|c|c|c|c|c|}
\hline Case & Age & Sex & Site & $\begin{array}{l}\text { Presenting } \\
\text { symptom }\end{array}$ & Duration & Ulceration & Initial treatment & Follow-up \\
\hline 1 & 65 & $\mathbf{M}$ & $\begin{array}{l}\text { Left palate } \\
\text { (hard) }\end{array}$ & $\begin{array}{l}\text { Swelling } \\
\text { noticed by } \\
\text { dentist }\end{array}$ & $?$ & No & Local excision & $3 \mathrm{yr}-$ no recurrence \\
\hline 2 & 50 & $\mathbf{M}$ & $\begin{array}{l}\text { Left hard/ } \\
\text { soft palate }\end{array}$ & Swelling & $?$ & No & Local excision & $2 \mathrm{yr}$-no recurrence \\
\hline 3 & 84 & $\mathbf{F}$ & Upper lip & Swelling & $2 \mathrm{yr}$ & No & $\begin{array}{l}\text { Local excision }+ \\
x \text {-ray therapy }\end{array}$ & $5 \mathrm{yr}-$ no recurrence \\
\hline 4 & 71 & $\mathbf{M}$ & Right palate & Swelling & $6-8 \mathrm{wk}$ & Yes & $\begin{array}{l}\text { Biopsy and radical } \\
\text { maxillectomy }\end{array}$ & $7 \mathrm{yr}$-no recurrence \\
\hline 5 & 53 & $\mathbf{F}$ & $\begin{array}{l}\text { Palate } \\
\text { (junction } \\
\text { hard/soft) }\end{array}$ & Swelling & $3 \mathrm{yr}$ & $?$ & Local excision & $\begin{array}{l}6 \mathrm{yr} \text {-recurrent nodule further } \\
\text { excision } \\
7 \mathrm{yr} \text {-further recurrence } \\
\text { Biopsy }+x \text {-ray therapy } 5000 \mathrm{r} \\
10 \mathrm{yr}-\text { still small residual } \\
\text { nodule on palate }\end{array}$ \\
\hline 6 & 56 & $\mathbf{M}$ & $\begin{array}{l}\text { Left buccal } \\
\text { mucosa }\end{array}$ & Swelling & $6 \mathrm{mth}$ & No & $\begin{array}{l}\text { Biopsy followed by } \\
\text { radical excision }\end{array}$ & $\begin{array}{l}8 \mathrm{yr} \text {-then left submandibular } \\
\text { node block dissection } \\
10 \frac{1}{2} \mathrm{yr}-\text { local recurrence in } \\
\text { parotid area. } X \text {-ray therapy } \\
2000 \mathrm{r} \\
14 \mathrm{yr} \text {-died, myocardial infarct. } \\
\text { No tumour recurrence }\end{array}$ \\
\hline
\end{tabular}

Table II Clinical features of six cases

was noticed at the junction of the hard and soft palates. The patient himself was unaware of the existence of the lesion. The abnormal area of mucosa was locally excised.

Sections of this lesion showed branching glandular spaces in the subepithelial connective tissue, lined by a double-layered columnar epithelium of 'oncocytic' type. Near the mucosal surface there was a direct transition from ducts lined by columnar epithelium to the surface squamous epithelium remi- niscent of the syringocystadenoma papilliferum? of the skin. A fairly dense infiltration of plasma cells 0 and lymphocytes was present in the connective ${ }_{\omega}^{N}$ tissue between the epithelial elements (fig 1).

No further treatment was carried out and thereo was no evidence of recurrence three years later.

\section{CASE 2}

A man aged 50 presented with a swelling at the junction of the hard and soft palates to the left of $\stackrel{D}{\circ}$ 


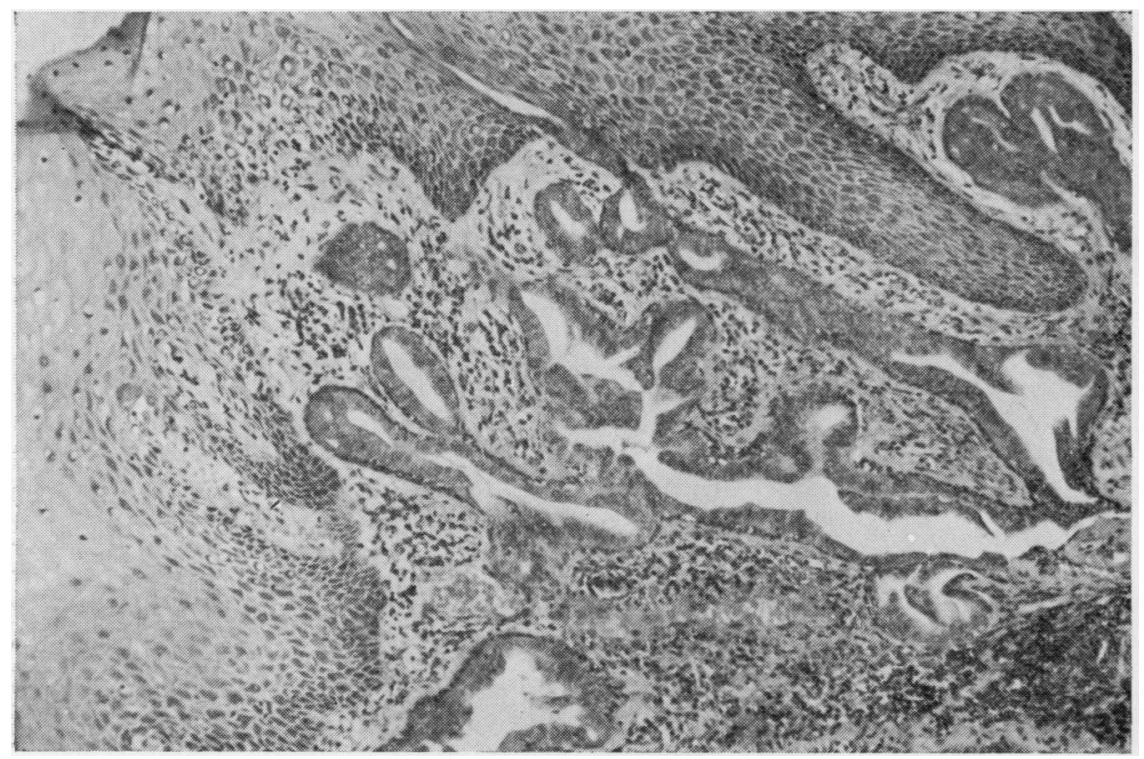

Fig 1 Case 1.

Oncocytic adenomatous

hyperplasia.

A low-power view

showing glandular

spaces in the

subepithelial connective

tissue $(\times 100)$. Note

the absence of

encapsulation in this

benign lesion.

the midline. The lesion was locally excised and histologically showed appearances almost identical with those of case 1 except that the stromal lymphocytic infiltrate was more marked, with formation of germinal centres in some areas. Of all the cases in the series, this one showed the closest resemblance to adenolymphoma (figs 2 and 3).

\section{CASE 3}

A woman of 84 presented with a swelling in the left side of the upper lip which had been present for two years. The tumour was removed by local dissection. Histologically it consisted of a well-defined nodule, $10 \mathrm{~mm}$ in diameter, composed of cords and ribbons of low columnar or cuboidal cells with central, uniform oval or round nuclei. The epithelium in some areas formed small glandular or cystic spaces containing grey mucoid secretion; where cystic dilatation occurred, the lining epithelium became flattened. Goblet-cell metaplasia was seen in some fields but no myoepithelial or oncocytic elements were recognized, the cell ribbons for the most part being one cell thick. Mitoses were not seen. The cell columns were supported by a delicate mucoid stroma containing thin-walled blood vessels (figs 4-6).

After local excision of the tumour, $x$-ray therapy of $1800 \mathrm{r}$ was given to the tumour site. Five years later the patient was well with no sign of recurrence of metastasis.

\section{CASE 4}

A man of 71 presented with a swelling on the right side of the hard palate which had been present for six to eight weeks. Examination revealed a smooth, firm swelling, $20 \mathrm{~mm}$ in diameter, with a central area of ulceration. $X$-ray showed no evidence of bone destruction in the hard palate, and films of the chest and antra were normal. A tissue fragment was removed for frozen section and reported as adenoid cystic carcinoma. After this diagnosis had been made a radical removal of the right maxilla with the hard palate and part of the alveolus was performed.

The excised specimen showed a shallow ulcer, 25 $\times 14 \mathrm{~mm}$, with a base of soft papillary tumour which extended down to the underlying bone of the hard palate. The tumour was not macroscopically cystic. Histological review of the biopsy and excision specimens showed appearances identical with those of case 3 with the exception that no goblet-cell metaplasia was seen. The tumour edge was again extremely well defined. After radical excision, the patient has remained well, with no recurrence or metastasis seven years later (figs 7 and 8).

\section{CASE 5}

A :53-year-old woman presented in 1965 with a three-year history of a swelling on the right side of the palate. This was excised and reported to be a mixed salivary adenoma (pleomorphic adenoma). 


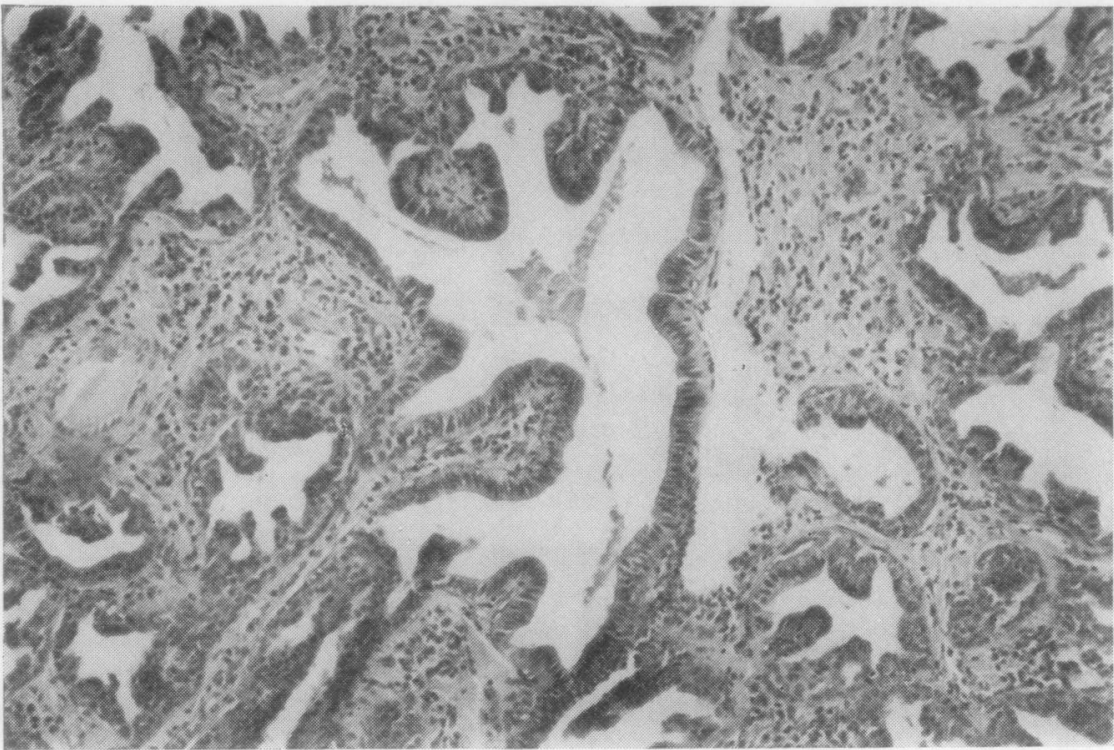

Fig 2 Case 2. Oncocytic adenomatous hyperplasia. A low-power view showing similar appearances to case 1 (× 100).

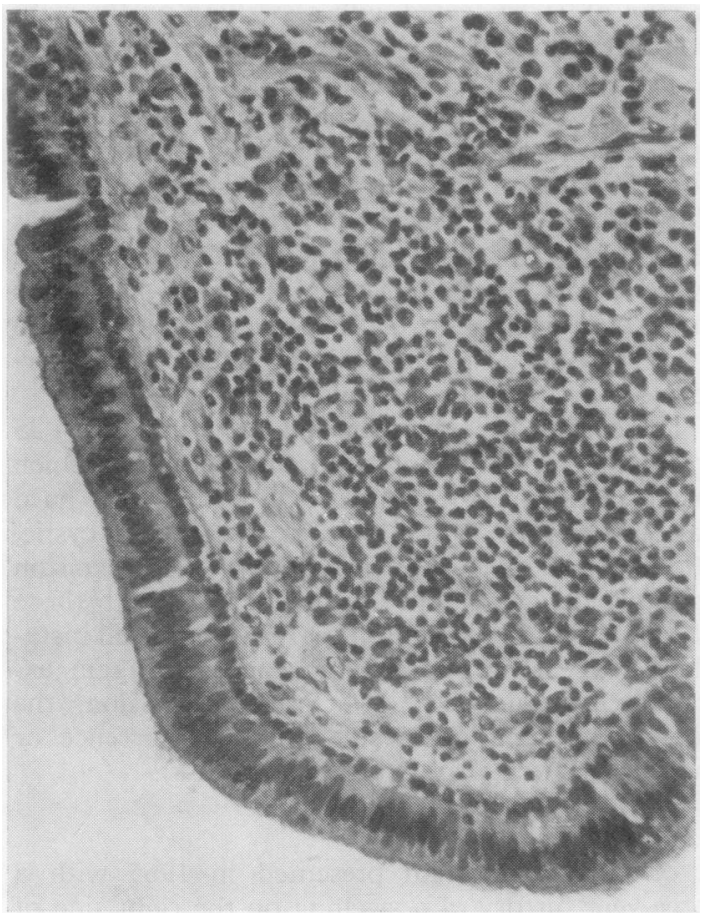

Fig 3 Case 2. Higher magnification to show type of epithelium present $(\times 380)$.
In 1971 she returned with a swelling of the palate which was excised locally. The following year the tumour had again recurred, although $x$-rays showed no evidence of bone involvement. A biopsy was taken and the recurrence was treated by radiotherapy (5600 r). When last seen in August 1975, a small residual nodule was still present on the soft palate but was gradually decreasing in size.

The histological appearances of both the original tumour and the recurrences were identical and again showed a papillary pattern, with ribbons and cords of cuboidal or columnar cells. Some areas, however, showed solid trabeculae and compact balls of epithelial cells, and intraluminal tufting was a marked feature, producing a glomerulus-like appearance in some areas. Goblet-cell or oncocytic metaplasia was not seen, nor were areas of 'mixed' or adenoid cystic pattern present.

This case showed features such as loss of cell polarity and multilayering of the cell columns which were absent from cases 1 and 2 . Occasional mitotic figures were noted. The surface of the neoplasm was ulcerated and inflamed, and as the material received was fragmented, it was not possible to assess the border between the tumour and surrounding tissue (fig 9).

CASE 6

A man aged 56 presented in 1957 with a swelling on 


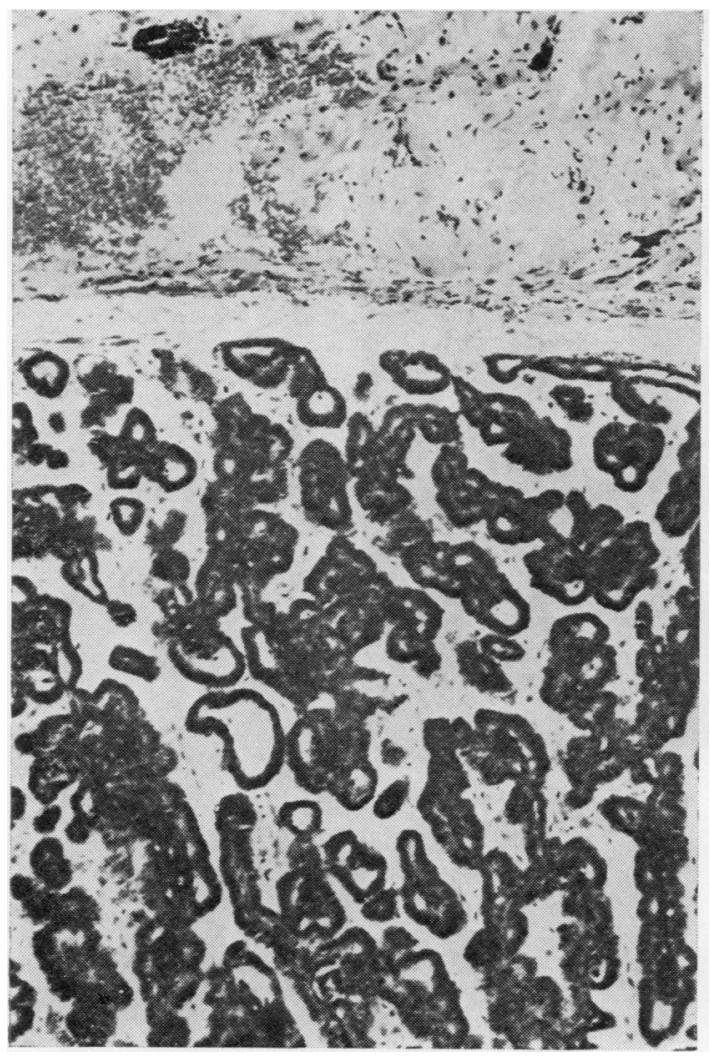

Fig 4 Case 3. Papillary adenoma.

$A$ low-power view showing general architecture and sharply defined edge of tumour $(\times 95)$.

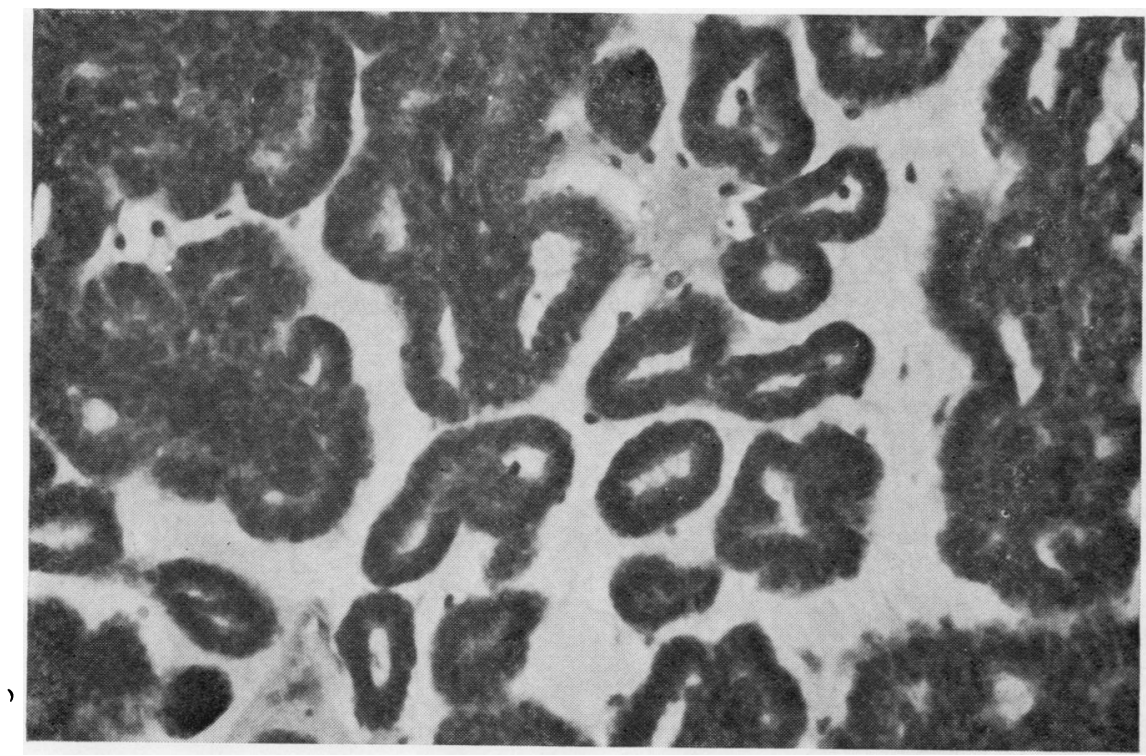

Fig 5 Case 3.

High-power view showing ribbons of columnar epithelium in a loose textured stroma $(\times 400)$. 


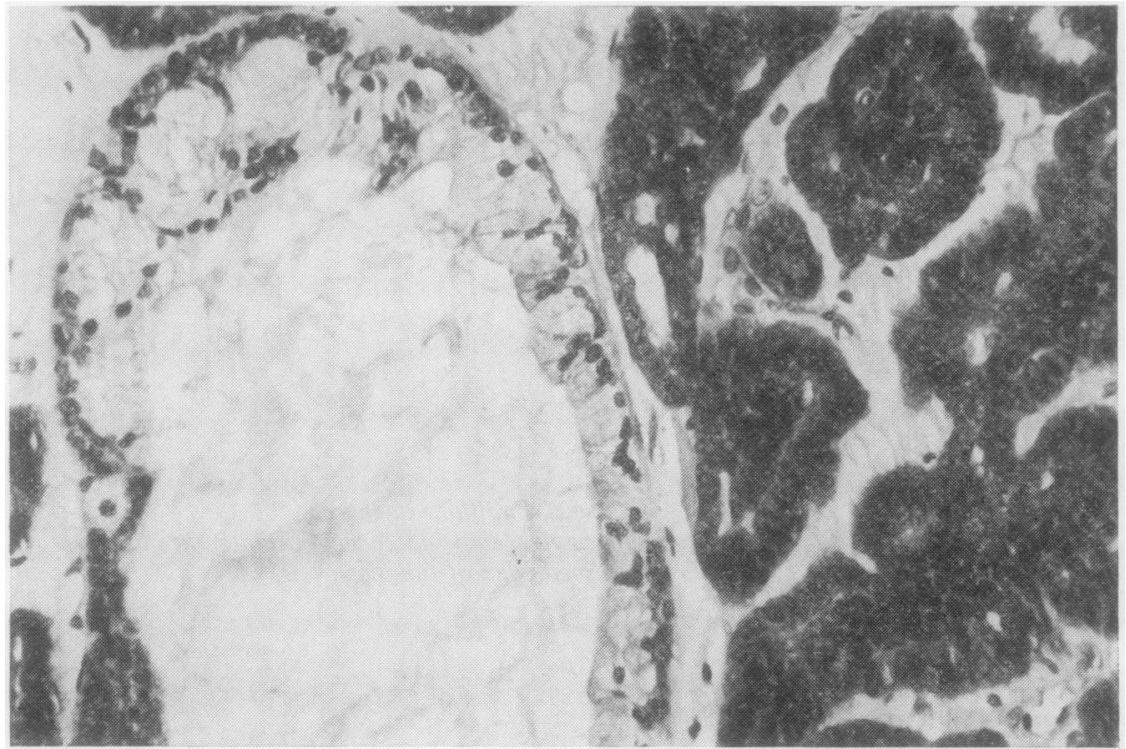

Fig 6 Case 3. Another field showing metaplasia to a mucus-secreting type of cell $(\times 400)$.

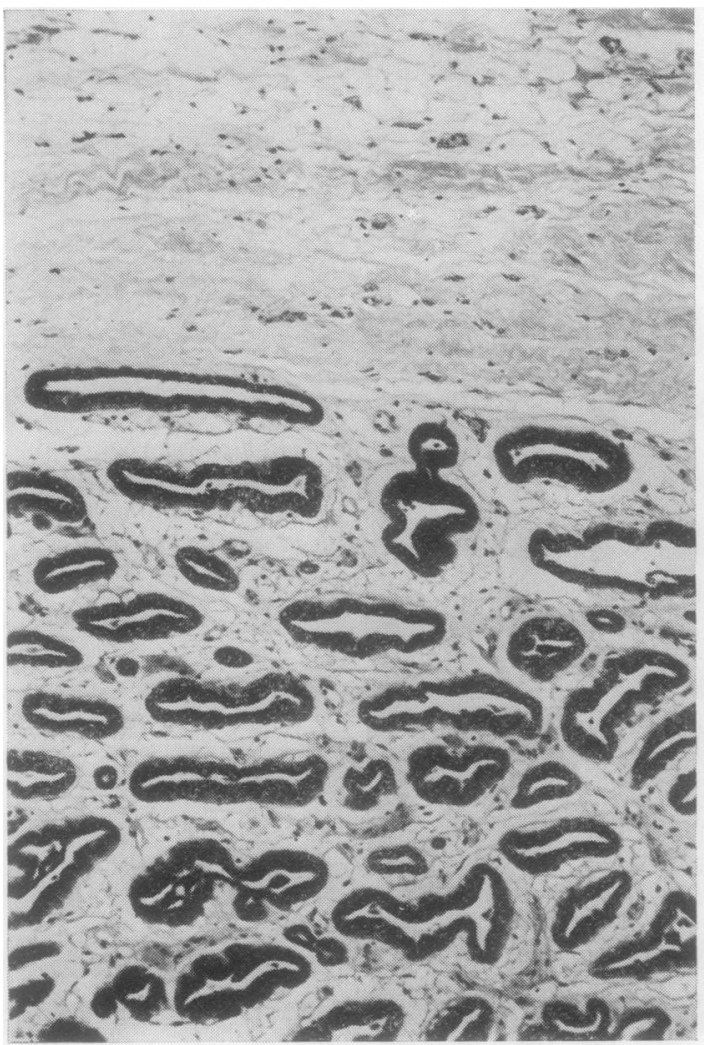

Fig 7 Case 4. Papillary adenoma.

A low-power view showing similar appearances to case 3 , again with a very well-defined edge ( $\times 95)$. 


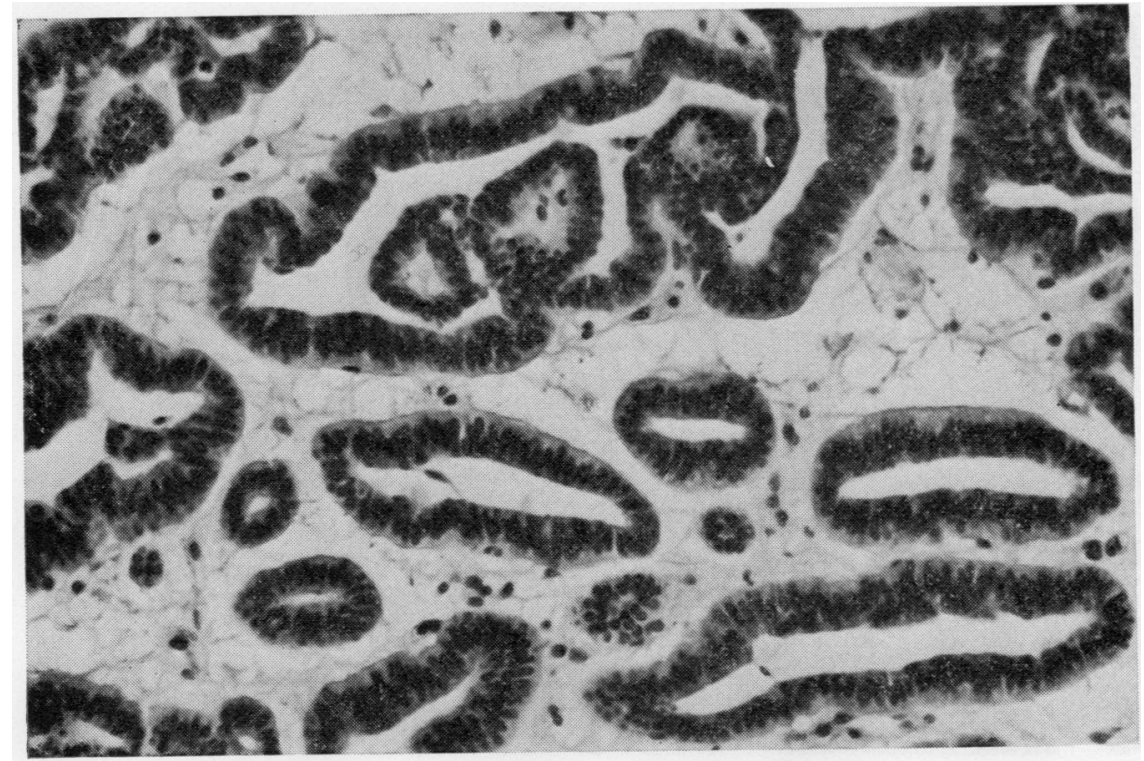

Fig 8 Case 4.

Higher magnification

showing ribbons of

columnar epithelium.

Note absence of solid epithelial areas as compared with cases 5 and $6(\times 400)$.

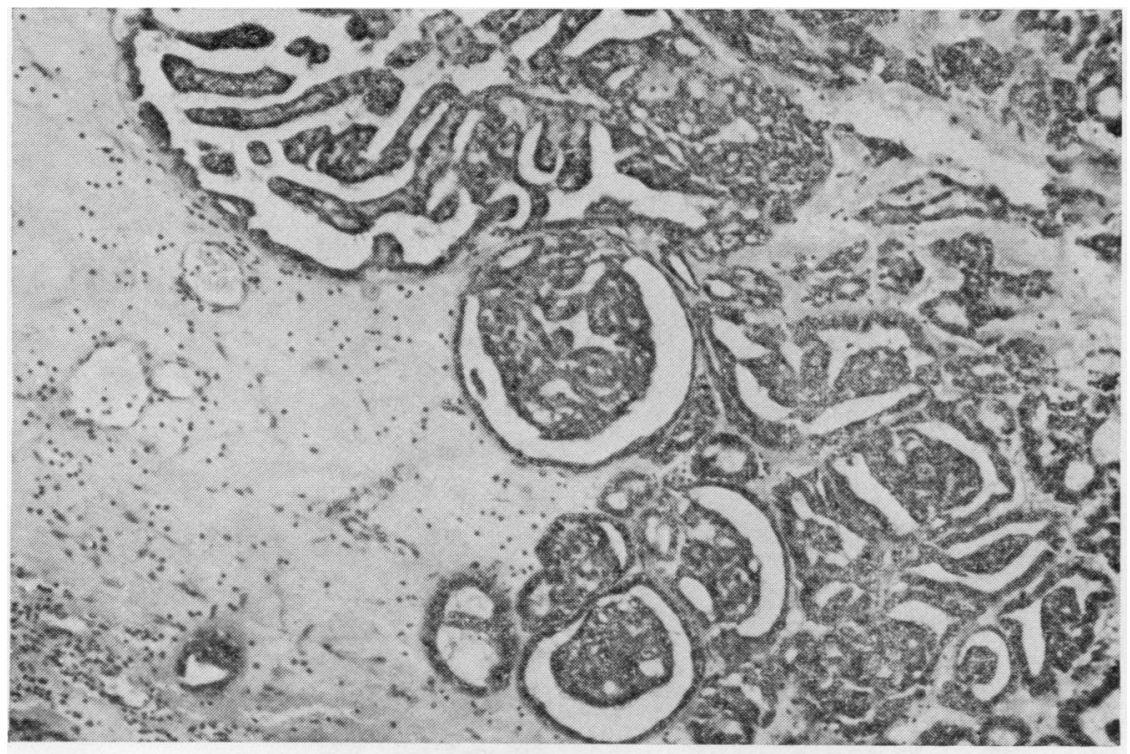

Fig 9 Case 5.

Higher magnification showing good examples of the glomerulus-like appearance produced by intraluminal tufting $(\times 250)$.

the mucosa of the left cheek which had been noticed six months previously. A biopsy was performed and reported as papillary adenocarcinoma. A radical excision of the lesion was carried out. The patient remained well for eight years but then developed a left submandibular swelling. A block dissection was performed, and one lymph node contained metastatic tumour. Two years later there was clinically recurrent tumour in the left parotid area and he was given $x$-ray therapy $(2000 \mathrm{r})$. He died in 1971 from a myocardial infarct with no evidence of locally recurrent tumour or metastases. 


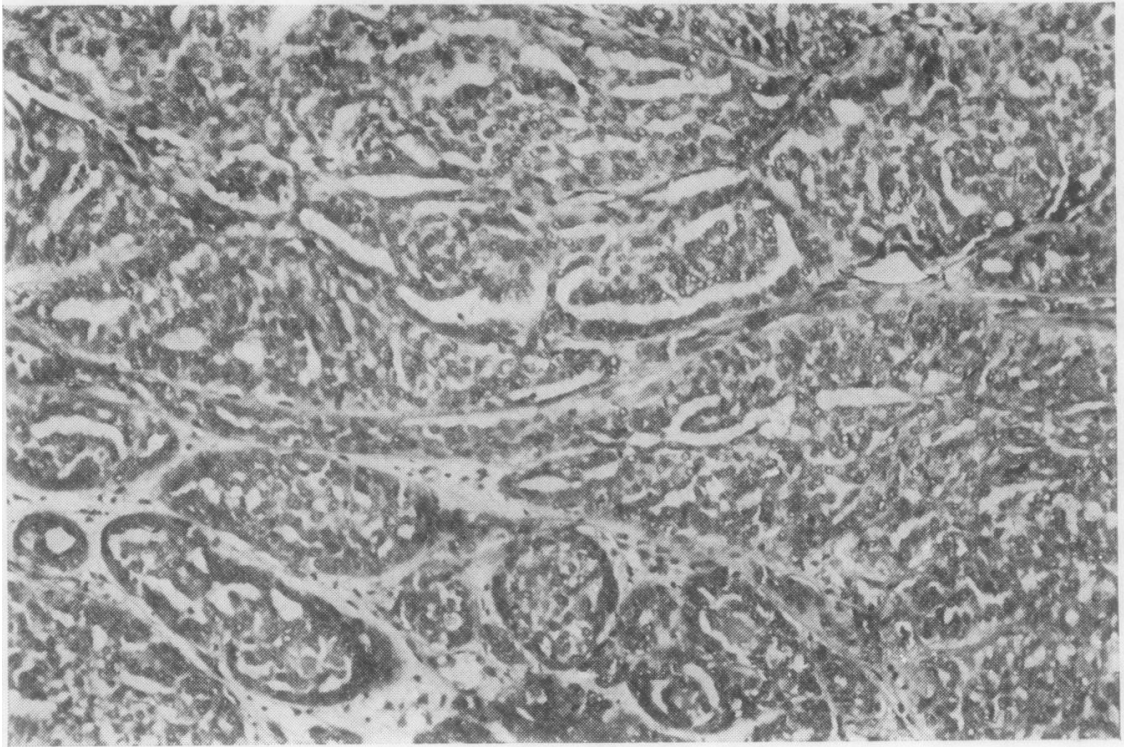

Fig 10 Case 6. Papillary adenocarcinoma.

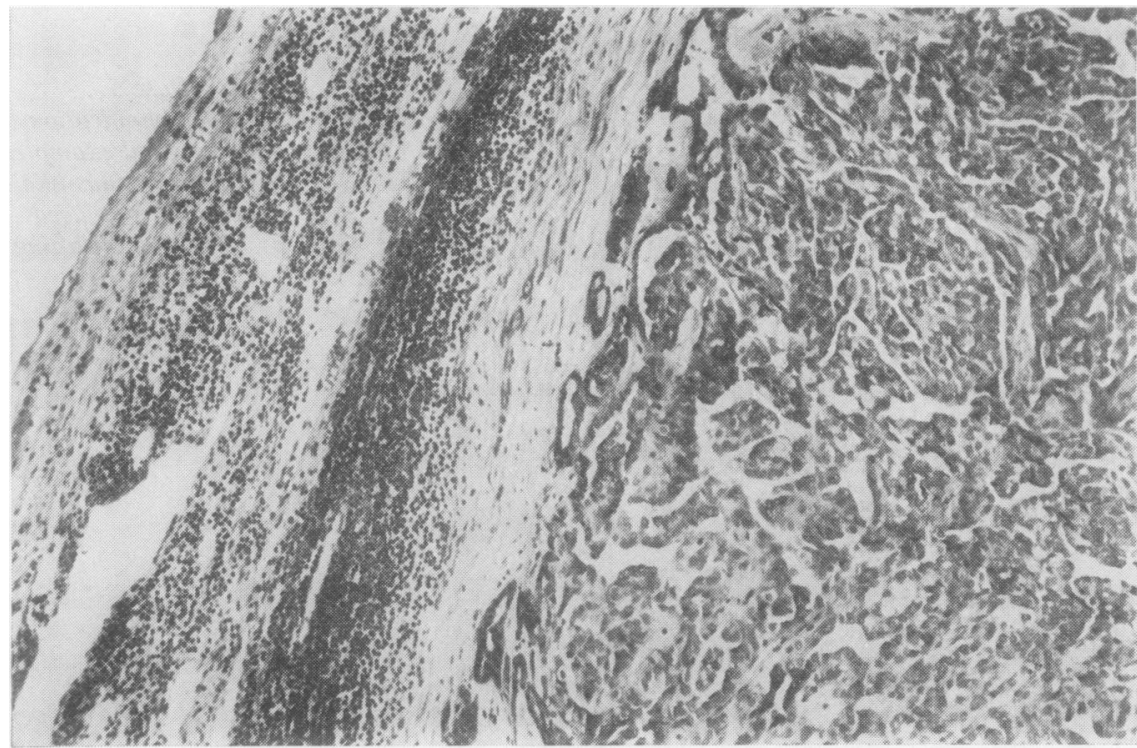

Fig 11 Case 6.

Metastatic papillary carcinoma in submandibular lymph node $(\times 100)$.

Histologically both the primary tumour and lymph node metastases from this case showed appearances identical with those of case 5. The edge of the primary tumour appeared well defined in many areas, but in others the border was ragged, with apparent infiltration of adjacent tissues (figs 10 and 11).

\section{Discussion}

Our six cases fall into three distinct histological $\stackrel{\oplus}{?}$ groups which we have designated focal oncocytic 0 adenomatous hyperplasia, papillary adenoma, and $\stackrel{\vec{P}}{\overrightarrow{0}}$ papillary carcinoma (table III). Cases 1 and 2, with $\stackrel{\odot}{\oplus}$ 


\begin{tabular}{|c|c|c|}
\hline Group & Type of lesion & Histological features \\
\hline 1 (cases 1 and 2) & Focal oncocytic adenomatous hyperplasia & $\begin{array}{l}\text { Non-encapsulated proliferation of ductal } \\
\text { epithelium with oncocytic change and variable } \\
\text { stromal lymphoid component }\end{array}$ \\
\hline 2 (cases 3 and 4 ) & Papillary adenoma & $\begin{array}{l}\text { Well-defined tumour with regular uniform } \\
\text { non-oncocytic epithelium }\end{array}$ \\
\hline 3 (cases 5 and 6) & Papillary carcinoma & $\begin{array}{l}\text { Basically similar pattern to group } 2 \text {, but } \\
\text { with multilayering, solid areas, and } \\
\text { possible invasion }\end{array}$ \\
\hline
\end{tabular}

Table III Summary of histology

oncocytic epithelium, most closely resemble the descriptions of 'papillary cystadenoma' given by other workers such as Bernier and Bhaskar (1958), Vellios and Shafer (1959), Calhoun et al (1965), and Parnes (1966). Most of these authors regard the lesion as of ductal origin and benign, and Evans and Cruickshank (1970) point out that such lesions may represent focal hyperplastic reactions rather than true tumours. Veronesi and Corbetta (1960) described two cases of 'adenolymphoma' of the lower lip. In these cases, in addition to the epithelial component, there was a prominent lymphoid stroma (with germinal centres in one case). One of their cases showed progression from oncocytic metaplasia of duct epithelium through a stage of periductal lymphocytic infiltration to a stage closely resembling adenolymphoma of the parotid.

In the light of these findings they suggested a possible alternative mechanism for the histogenesis of adenolymphoma, beginning with oncocytic metaplasia of duct epithelium followed by periductal lymphocytic infiltration and eventual atrophy of the acinar tissue, leaving dilated ducts in a lymphocytic stroma. A more recent paper (Allegra, 1971) advances a similar theory for the histogenesis of adenolymphoma based on light, fluorescent, and electron microscopic studies and suggests that the tissue reaction may be of the delayed hypersensitivity type.

There is clearly a close relationship between adenolymphoma and papillary cystadenoma without a lymphoid component. Small foci of oncocytic metaplasia and periductal lymphocytic infiltration are not uncommon adjacent to parotid adenolymphomas (Whittaker, 1972), and it seems to us that the mechanism described by Veronesi and Corbetta (1960) and Allegra (1971) may well explain some cases. We also believe, however, that most cases, particularly in the parotid area, do arise from salivary duct inclusions within lymph nodes and that the theories are not mutually exclusive. Such an origin has been convincingly demonstrated by Azzopardi and Hou (1964). We agree with Evans and Cruickshank (1970) that these small, non-

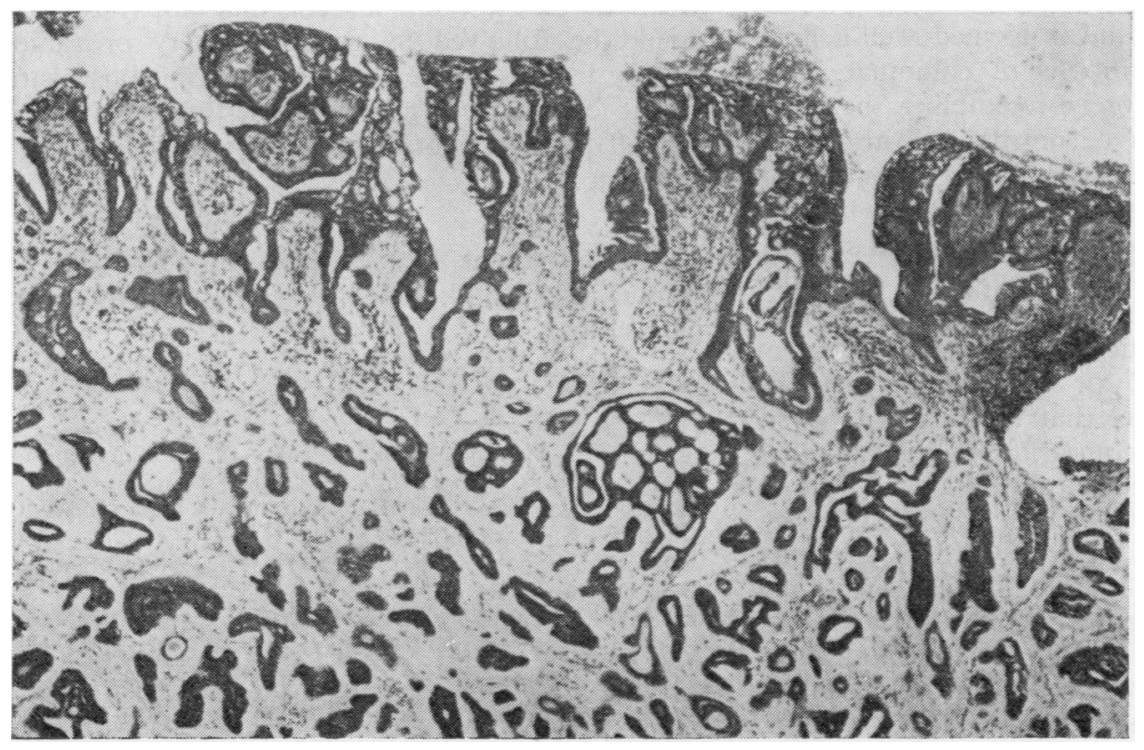

Fig 12 An adenoid cystic carcinoma of the palate with a papillary surface (× 100). 
encapsulated lesions may well represent focal hyperplasia of duct epithelium rather than true neoplasms and would regard the term 'oncocytic adenomatous hyperplasia' (Kleinsasser et al, 1966) as appropriate. Both our cases showed a papillary surface with a transition from ductal to squamous epithelium reminiscent of the non-vulval superficial hidradenoma of the skin (Lennox, 1954). Castigliano and Gold (1954) described such an appearance in a tumour of the hard palate, which they called intraductal papilloma'. They ascribed the appearance to a neoplastic process affecting many ducts of the palatal mucous glands. Recently, Abrams and Finck (1969) reported two tumours, one in the parotid and one in the palate, again showing papillary surfaces with a transition from surface squamous epithelium to ductal epithelium in the deeper layers. They proposed the name 'sialadenoma papilliferum' in view of the similarity of these tumours to the 'syringocystadenoma papilliferum' of the skin, and interpreted the surface squamous epithelium as having arisen by metaplasia of the ductal columnar epithelium due to longstanding chronic irritation. Similar cases have been reported by Crocker et al (1972) and Jensen and Reingold (1973), and we have also observed such an appearance in an otherwise typical adenoid cystic carcinoma of the palate (fig 12). Lennox (1954), dealing with hidradenomata of the skin, attributed the mixture of epithelia to regrowth of remaining fragments of surface squamous epithelium rather than to metaplasia, and also stated that often a group of ducts rather than a single duct is involved in the neoplastic process. These cases emphasize the close histogenetic relationships between sweat gland and salivary gland neoplasms.

In contrast, cases 3 and 4 formed well-defined nodules consisting of ribbons of columnar, nononcocytic epithelium closely resembling the inner layer of columnar cells of normal salivary gland ducts. It is interesting that lymphocytic infiltration was not a feature of these tumours except where inflammation had occurred near an ulcerated surface. We have been unable to find descriptions of similar tumours in the literature. Possibly other workers have included them under the general heading of 'pleomorphic adenoma' or 'cellular variants of mixed tumours'. We feel that they should be included in the group 'Monomorphic adenoma-other types' in the recently published WHO classification of salivary gland tumours (Thackray and Sobin, 1972). Finally, cases 5 and 6, while of basically similar pattern to cases 3 and 4 , showed additional features such as multilayering of epithelium and solid epithelial areas, and it is noteworthy that both these tumours subsequently recurred. In case 5 , initial excision may have been incomplete; in case 6 , however, a radical excision was followed eight years later by metastasis to a submandibular lymph node. $\overrightarrow{0}$ We consider all of our cases to have arisen from ducts of minor salivary glands. The columnar $\overrightarrow{\vec{F}}$ epithelium of these tumours closely resembles ${ }_{-}^{+}$ normal duct epithelium. In some cases, oncocytic metaplasia has taken place and the tumour re- $\overline{\bar{c}}$ sembles an adenolymphoma without the lymphoid $\overrightarrow{\widetilde{\phi}}$ component. Lymphocytes and plasma cells may ac- $\frac{0}{0}$ cumulate in large numbers, and the resemblance to ${ }^{\infty}$ the adenolyphoma then becomes very close, as in the $\overrightarrow{0}$ cases of Veronesi and Corbetta (1960).

Some workers have reported malignant variants $\vec{\circ}$ of these tumours (Brooks et al, 1956; Vellios and Shafer, 1959; Edwards, 1960), but in some cases histological details are not given, and in otherse follow-up has not been adequate at the time of publication.

Cases 5 and 6 produced recurrences after six ando eight years respectively, and histologically these two cases showed certain features such as multilayering $(\overrightarrow{)}$ solid epithelial areas, and loss of cell polarity which $\mathbb{D}$

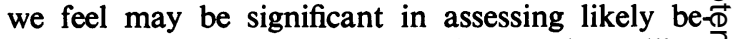
haviour. We regard these cases as low-grade papillary? carcinomas. At the same time, while none of the other cases showed histologically suspicious features $\overrightarrow{r 0}$ the maximum follow-up period as yet is only sekens years, and one of these patients also had radi therapy. Ulceration does not necessarily imfivo malignancy, as by their structure (often soft with as delicate vascular stroma) and situation within the oral cavity these papillary tumours are liable to trauma and subsequent infection.

In the present state of knowledge of these com $\overrightarrow{\vec{O}}$ paratively rare tumours it seems that biopsy excision should be followed by radical surgery or radio therapy in those patients showing suspicious histo logical features such as those described above, anक that all patients should be subjected to long-term follow-up.

We wish to thank Dr B. Peach for permission to include case 2, and Miss J. A. Berry for typing the manuscript.

\section{References}

Abrams, A. M. and Finck, F. M. (1969). Sialadenom papilliferum. Cancer (Philad.), 24, 1057-1063.

Allegra, S. R. (1971). Warthin's tumour. A hypersensitivit స్టు disease? Hum. Path., 2, 403-420.

Azzopardi, J. G. and Hou, L. T. (1964). The genesis of adenox lymphoma. J. Path. Bact., 88, 213-218.

Bernier, J. L. and Bhaskar, S. N. (1958). Lymphoepithelia夰 lesions of salivary glands. Cancer (Philad.), 11, 1156-1179\% Brooks, H. W., Hiebert, A. E., Pullman, N. K., and Stofer B. E. (1956). Papillary cystadenoma of the palate. Orat Surg., 9, 1047-1050. 
Brown, R. L., Bishop, E. L., and Girardeau, H. S. (1959). Tumors of the minor salivary glands. Cancer (Philad.), 12, 40-46.

Calhoun, N. R., Cerine, F. C., and Mathews, M. J. (1965). Papillary cystadenoma of the upper lip. Oral Surg., 20, 810-814.

Castigliano, S. G. and Gold, L. (1954). Intraductal papilloma of the hard palate. Oral Surg., 7, 232-238.

Chaudhry, A. P., Gorlin, R. J., and Mitchell, D. F. (1960). Papillary cystadenoma of minor salivary gland origin. Oral Surg., 13, 452-454.

Chaudhry, A. P., Vickers, R. A., and Gorlin, R. J. (1961). Intraoral minor salivary gland tumors. Oral Surg., 14, 1194-1226.

Crocker, D. J., Cavalaris, C. J., and Finch, R. (1970). Intraoral minor salivary gland tumors. Oral Surg., 29, 60-68.

Crocker, D. J., Christ, T. F., and Cavalaris, C. J. (1972). Sialadenoma papilliferum-report of case. J. oral Surg. Anesth., 30, 520-521.

Edwards, E. G. (1960). Tumors of the minor salivary glands. Amer. J. clin. Path., 34, 455-463.

Epker, B. N. and Henny, F. A. (1969). Clinical, histopathologic, and surgical aspects of intraoral minor salivary gland tumors. J. oral Surg Anesth., 27, 792-804.

Evans, R. W. and Cruickshank, A. H. (1970). Epithelial Tumours of the Salivary Glands (Major Problems in Pathology, Vol. I). Saunders, Philadelphia.

Fine, G., Marshall, R. B., and Horn, R. C., Jr. (1960). Tumors of the minor salivary glands. Cancer (Philad.), 13, 653-669.

Foote, F. W. and Frazell, E. L. (1954). Tumors of the Major Salivary Glands (Atlas of Tumor Pathology, Sect. 4, fasc. II). Armed Forces Institute of Pathology, Washington, D.C.

Hobaek, A. (1949). Intraoral mucous and salivary mixed tumours. Acta radiol. (Stockh.), 32, 229-247.

Jensen, J. L. and Reingold, I. M. (1973). Sialadenoma papilliferum of the oral cavity. Oral Surg., 35, 521-525.

Kleinsasser, O., Klein, H. J., Steinbach, E., and Hubner, G. (1966). Onkocytäre adenomartige Hyperplasien, Adenolymphome und Onkocytome der Speicheldrüsen. Arch. klin exp. Ohr.-, Nas.-, u. Kehlk.-Heilk. 186, 317-336. Quoted by Evans and Cruickshank (1970).

Lennox, B. (1954). The superficial hidradenomata. J. Path. Bact., 67, 553-562.

Lucas, R. B. (1973). Pathology of Tumors of the Oral Tissues, 2nd edition. Churchill Livingstone, Edinburgh and London.

Parnes, E. I. (1966). Papillary cystadenoma. Oral Surg., 21, 782-785.

Skorpil, F. (1941). Über das Cystadenoma papillare der grossen und kleinen Speicheldrüsen. Frankfurt Z. Path., 5, 39-59.

Stuteville, O. H. and Corley, R. D. (1967). Surgical management of tumors of intraoral minor salivary glands. Cancer (Philad.), 20, 1578-1586.

Thackray, A. C. and Sobin, L. H. (1972). Histological Typing of Salivary Gland Tumours (International Histological Classification of Tumours, No. 7). World Health Organisation, Geneva.

Vellios, F. and Davidson, D. (1955). The natural history of tumors peculiar to the salivary glands. Amer. J. clin. Path., 25, 147-157.

Vellios, F. and Shafer, W. G. (1959). Tumors of the intraoral accessory salivary glands. Surg. Gynec. Obstet., 108, 450456.

Veronesi, U. and Corbetta, L. (1960). Adenolymphoma of the lower lip. Acta oto-laryng. (Stockh.), 52, 1-6.

Whittaker, J. S. (1972). Unpublished observations. 